\title{
PROFIL INDEKS MASSA TUBUH DAN KEBUGARAN JASMANI ANAK SEKOLAH MENENGAH PERTAMA SANTA MARIA FATIMA
}

\author{
Norman $^{1}$, Ruliando Hasea Purba ${ }^{2}$, Iwan Hermawan ${ }^{2}$ \\ ${ }^{1}$ Program Studi Ilmu Keolahragaan \\ ${ }^{2}$ Fakultas Ilmu Keolahragaan Universitas Negeri Jakarta, Kampus B, Jakarta
}

\begin{abstract}
Abstrak: Penelitian ini bertujuan untuk mengetahui atas dasar kurangnya kesadaran akan kebugaran jasmani dan indeks massa tubuh yang ideal pada siswa putra dan putri usia 13-15 Tahun di SMP Santa Maria Fatima II Kampung Pulo, Jatinegara Jakarta Timur. Sampel peneliitian ini adalah siswa santa maria fatima dari jumlah populasi 150 siswa maka didapat 60 orang siswa yang menjadi sampel penelitian secara kriteria. Penelitian ini menggunakan metode deskriptif dengan statistic berupa angket dengan tes dan pengukuran. Tes untuk indeks massa tubuh menggunakan tinggi badan dan berat badan, sedangkan untuk tes kebugaran jasmani menggunakan lari 50m, angkat tubuh, baring duduk, vertical jump dan lari 800/1000m. Berdasarkan hasil penelitian didapatkan hasil nilai-nilai yang menjadi ciri bahwa indeks massa tubuh dan kebugaran jasmani siswa sekolah menengah pertama santa maria fatima yang normal. Untuk klasifikasi kebugaran jasmani siswa mendapatkan hasil yang cukup dengan rata-rata. Tes Kebugaran Jasmani untuk 50 Meter dengan rata-rata 8,3 detik, Gantung Angkat Tubuh/Gantung Angkat Siku dengan rata-rata 8,5, Lari 800/1000 Meter dengan rata-rata 3,8 menit dikategorikan "Sedang" dan Tes Kebugaran Jasmani untuk Baring Duduk dengan rata-rata 22,73 dan Verctical Jump dengan rata-rata 44,93 dikategorikan "Baik". Dapat disimpulkan bahwa siswa SMP Santa Maria Fatima berada dalam kategori yang cukup baik.
\end{abstract}

\section{Kata Kunci: Indeks Massa Tubuh dan Kebugaran Jasmani}

\section{PENDAHULUAN}

Perkembangan ilmu pengetahuan dan teknlogi semakin pesat, ini gaya hidup masyarakat telah mengalami banyak perubahan, semua orang menginginkan hidup yang serba cepat dan instan. Semua hidup dengan teknologi yang semakin maju baik orang tua, remaja, bahkan hingga anak kecil. Hampir semua orang kini mempunyai alat komunikasi dan peralatan yang canggih serta sangat menarik untuk digunakan. Seperti permainan elektronik yang terdapat saat ini, dimana alat tersebut memiliki berbagai fitur permainan yang bagus dan menarik. Permainan playstation dan jenis peralatan permainan elektronik lainnya merupakan salah satu jenis permainan yang sangat sering anak lakukan.Bahkan sekarang ini tidak jarang para orangtua yang tidak sungkan untuk memberikan sebuah gadget kepada anaknya sebagai alat pemuas keinginan anak tersebut, dimana pada alat simpel tersebut terdapat banyak jenis permainan canggih yang dapat membantu anak untuk mengisi waktu senggang mereka. Namun karena terlalu asiknya memainkan permainan yang canggih itu, anak tersebut menjadi lupa akan waktu seperti waktu untuk belajar, bermain, kumpul bersama keluarga bahkan di sore hari bersama teman. 
Olahraga merupakan salah satu aktivitas fisik yang memiliki dimensi yang komplek. Dalam berolahraga setiap individu memiliki tujuan yang berbeda-beda antara lain berprestasi meningkatkan kebugaran dan rekreasi. Dalam berolahraga banyak manfaat yang diperoleh dalam melakukan kegiatan olahraga, disamping menjadikan tubuh yang sehat dapat juga meningkatkan jantung, paru-paru, mengurangi lemak, menurunkan kadar gula darah, memperkuat sendi, otot, tulang dan menambah semangat dalam menjalani aktivitas kehidupan seharihari. Kegiatan olahraga yang umum dapat meningkatkan kesehatan tubuh diantaranya yaitu: jalan, lari, berenang, bersepeda dan senam aerobik.

Olahraga merupakan sebagian dari budaya kehidupan lama dianggap cara yang tepat untuk meningkatkan kesehatan. Olahraga adalah suatu bentuk kegiatan fisik bila dilaksanakan dengan tepat dan terarah, dalam arti bahwa telah diperhitungkan pelaksanaannya berdasarkan kepada adanya keterbatasan dari tubuh manusia menghadapi beban kerja fisik dan kelebihan manusia menghadapi tekanan-tekanan yang semakin meningkat.

Hal inilah yang membuat mereka menjadi lupa akan waktu dan membuat mereka kurang dalam melakukan aktifitas gerak tubuh sehingga tubuh mereka mengalami kelemahan otot dan mudah lelah. Hal ini juga akan berdampak kurang baik bagi anak sebab dapat menghambat pertumbuhan tubuh anak. Akibatnya anak sering mengalami kelelahan ketika mengerjakan sesuatu hal, baik itu ketika melakukan pekerjaan di rumah maupun ketika anak sedang mengikuti pembelajaran olahrga di sekolah.

Sekolah merupakan tempat dimana anak dapat belajar baik dari tingkat terendah yaitu Taman KanakKanak (TK) sampai pada tingkat Universitas.Di dalam sekolah tidak hanya belajar ilmu berhitung, bahasa, sosial, dan lain-lain.Salah satu pembelajaran yang diikuti anak di sekolah ialah pembelajaran olahraga. Namun, sekarang ini banyak anak yang mengganggap olahraga hanya sekadar aktifitas bergerak, berlari, berkeringat namun tidak tahu apa manfaat dari olahraga tersebut, sehingga membuat anak tersebut kurang menyukai pelajaran olahraga sebab materi yang disampaikan cenderung monoton, padahal seharusnya olahraga seharusnya menjadi salah satu pelajaran favorit anak.

Lari merupakan salah satu olahraga yang diminati banyak kalangan khususnya bagi anak karena yang aman, murah, dan mudah dilakukan dimana saja seperti di jalan perkomplekan, di taman dan di stadion olahraga. Lari memiliki banyak manfaat bagi kesehatan tubuh dengan waktu $30-120$ menit dapat bermanfaat mengurangi resiko penyakit jantung, mencegah stroke, osteopororsis dan gangguan kesehatan lainnya. Berdasarkan fenomena tersebut terlihat bahwa lemahnya fisik yang terjadi pada anak dikarenakan jarangnya anak tersebut melakukan aktifitas gerak dan olahraga di luar jam pelajaran sekolah serta materi pelajaran yang di berikan cenderung monoton.

Adapun pencapaian anak saat ini bukan hanya dilihat dari keterampilan teknik individu yang dimilikinya, tetapi juga kondisi fisik yang bagus tentunya, yang tentunya didukung oleh asupan gizi yang baik pula sehingga membuat anak tersebut dapat tampil secara maksimal dan optimal. Karena kondisi fisik yang baik merupakan fondasi awal untuk membangun pengembangan komponen biomotorik, yang berguna 
untuk menunjang aktivitas anak untuk kegiatan sehari-hari.

Akhirnya terlihat bahwa anak sekolah menengah pertama sekarang inimempengaruhi pembelajaran olahraga yang monoton terhadap tingkat indeks massa tubuh dan kebugaran jasmani dikarenakan anak yang kurang antusias dalam melakukan kegiatan olahragra. Dari uraian di atas peneliti tertarik untuk melakukan penelitian ini untuk mengetahui lebih jauh tentang profil indek masa tubuh dan kebugaran jasmani anak sekolah menengah atas

Tinjauan Pustaka. Profil menurut kamus Bahasa Indonesia adalah pandangan dari samping (tentang wajah orang), lukisan (gambar) orang dari samping, sketsa biografis, penampang (tanah, gunung, sebagainya) grafik iktisar yang memberikan fakta tentang hal-hal khusus. Umumnya kata profil digunakan untuk kepentingan dan tujuan sebagai contoh profil atlet menunjukan bentuk atau bangunan tubuh dengan semua kondisi dan potensi yang dimiliki, terkait dengan bidang kerja gerak fisik sebagai olahragawan. Teori belajar sosial dari Bandura, didasarkan pada konsep saling menentukan, tanpa penguatan, dan pengaturan diri/berfikir.

Saling menentukan: Pendekatan yang menjelaskan tingkah laku manusia dalam bentuk interaksi timbal balik yang terus menerus antara determinan kognitif. Tanpa penguatan: menurut bandura reseinforsemen penting dalam menentukan apakah tingkah laku akan terus terjadi apa tidak, tetapi itu bukan satu-satunya pembentukan tingkah laku. Orang dapat belajar melakukan sesuatu hanya dengan mengamati dan kemudian mengulang apa yang dilihatnya. Pengaturan diri: teori belajar tradisional sering terhalang oleh ketidaksenangan atau ketidakmampuan mereka untuk menjelaskan proses kognitif. Konsep bandura menempatkan manusia sebagai pribadi yang dapat mengatur diri sendiri. Ada tiga macam gaya hubungan interpersonal, yakni: kecenderungan mendekat, kecenderungan menentang ataut kecenderungan menjauh.

Indek adalah rasio antara dua unsur kebebasan tertentu yang mungkin menjadi ukuran atau ciri tertentu. Massa adalah ukuran sejumlah materi yang dimilikinoleh suatu benda yang didefinisikan baik oleh sifat kelembaman benda itu maupun pengaruh gravitasi bumi pada bendabenda lain dalam fisika. Tubuh adalah keseluruhan jasad manusia atau binatang yang kelihatan dari ujung kaki sampai ujung rambut. Jadi yang dimaksud dengan indeks massa tubuh adalah rasio antara berat badan dan tinggi badan yang diukur dari ujung kaki sampai ujung rambut.

Indeks Massa Tubuh (BMI) tidak lain angka yang menunjukkan apakah seseorang terlalu berat untuk tinggi mereka. Gemuknya tidaknya seseorang tidak cuma dilihat dari berat badannya saja, melainkan dihitung juga berdasarkan perbandingan dengan tinggi badan. Indeks massa tubuh adalah berat badan dalam kilogram dibagi dengan tinggi badan pangkat dua dalam meter.

\section{KERANGKA BERPIKIR}

Indeks massa tubuh bermanfaat untuk mengukur dan membandingkan berat badan seseorang yang dibagi dengan kuadrat dari tinggi badannya. Indeks massa tubuh mempengaruhi seorang anak dalam melakukanaktivitas sehari-hari. Dengan mengetahui indeks massa tubuh anak, kita dapat mengetahui tubuh yang ideal bagi siswa. Melalui olahraga diharapkan anak mampu untuk meningkatkan kebugaran jasmani anak yang akhirnya dapat mempengaruhi tubuh mereka 
menjadi lebih kuat dan meningkatkan kebugaran jasmani dapat diperoleh melalui latihan yang teratur, sistematis dan berulang-ulang. Untuk menigkatkan kebugaran jasmani seseorang perlu metode atau cara latihan yang baik dan sesuai.

Oleh karena itu profil sekolah dapat dijadikan sebagai salah satu upaya untuk mengetahui tingkat indeks massa tubuh dan kebugaran jasmani anak. Dalam penelitian ini, yang akan menjadi focus penelitian ini anak akan diukur tinggi badan, tinggi badan dan tingkat kebugaran jasmaninya melalui Tes Kebugaran Jasmani Indonesia (TKJI) pada tes awal. Lalu, setelah diketahui hasil dan indeks massa tubuh dan tingkat kebugaran jasmani anak tersebut apakah baik, sedang atau bahkan kurang, untuk mengetahui profil indeks massa tubuh dan kebugaran jasmani sekolah menengah pertama santa maria fatima.

\section{METODE}

Penelitian menggunakan metode deskriptif kualitatif yaitu suatu metode penelitian yang dilakukan dengan tujuan utama untuk membuat gambaran atau deskripsi tentang suatu keadaan secara objektif, dengan teknik survey penyebaran angket sebagai instrumen dalam pengumpulan data.

Populasi pada penelitian ini adalahDalam penelitian ini yang menjadipopulasi adalah anak Sekolah menengah atas di SMP Santa Maria Fatima II yang berjumlah 150 murid.

Sampel adalah dengan purposive sampling yaitu populasi dijadikan sampel penelitian untuk anggota fitness bejumlah 60 orang kriteria sampel sebagai berikut : Pernah melakukan olahraga joging. Mengetahui tentang dehidrasi. Laki-laki dan perempuan bersedia mengisi angket.
Kriteria Kehilangan sampel : Tidak Mengikuti Tes. Tidak mengetahui tentang dehidrasi. Tidak mau mengisi angket.

Instrumen Penelitian. Instrumen yang digunakan dalam penelitian ini adalah menggunakan kuesioner yang bersifat tertutup, yaitu kuesioner yang telah disediakan jawabannya sehingga responden tinggal memilih.Kuesioner yang digunakan berbentuk pernyataan berjumlah 30 soal.

Teknik pengumpulan data. Dalam penelitian ini yaitu dengan menggunakan tes dan pengukuran komponen kondisi fisik terhadap siswa smp santa maria fatima. Dalam melakukan penelitian, ada tahap-tahap yang harus dilakukan, yaitu pertama adalah menentukan populasi, populasi yang dipilih adalah siswa santa maria fatima, setelah itu menentukan sampel, sampel yang ditentukan berdasarkan kriteria yang ditentukan, setelah itu sampel melakukan tes satu persatu dan dicatat hasilnya di formulir yang dibagikan kepada semua sampel. Awalnya sampel melakukan tes indek masa tubuh setelah semua sampel selesai, sampel melakukan tes komponen kesegaran jasmani dan hasilnya akan disesuaikan dengan norma dari setiap komponen kondisi fisik tersebut.

Teknik yang digunakan untuk mengolah data adalah teknik statistik deskriptif yaitu menjumlahkan dari setiap hasil tes yang dilakukan dan akan diberikan kesimpulan untuk mengetahui dasil dari tiap-tiap item tes.

Rumus-rumus yang berlaku adalah:

1. Menentukan nilai tertinggi dari tiap item tes

2. Menentukan nilai terendah dari tiap item tes 
3. Menentukan rentang/range dari selisih antara nilai tertinggi dan nilai terndah

4. Rata-rata nilai keseluruhan tiap item tes.

5. Simpangan baku dari nilai tes yang muncul pada hasil penelitian:

6. Median : data nilai yang paling tengah setelah disusun menurut hasilnya

7. Modus : data yang sering muncul diantara nilai datadata

\section{HASIL DAN PEMBAHASAN}

Deskripsi Data. Setelah dilakukan pengambilan data, kemudian peneliti menghitung dengan petunjuk teknik pengolahan data.Untuk mengetahui hasil data penelitian yang telah dilaksanakan, maka langkah selanjutnya peneliti melakukan analisis data dan pengolahan data terhadap hasil penelitian berupa angket yang diisi oleh responden.Berikut data lengkapnya.

\section{PemahamanAnggota Fitness Tentang Saat Joging.}

Di bawah ini disajikan data mengenai pemahaman anggota fitness tentang saat joging. Informasi pemahaman anggota fitness tentang saat joging dengan nilai tertinggi sebesar 100 dan nilai terendah 0 , dengan rentang nilai 100 dan nilai ratarata 57,3 dan memiliki standar deviasi 25,58 .

Dari hasil perhitungan dimensi saat joging, terdapat 2 anggota fitness yang dapat menjawab semua pertanyaan 5 soal dengan benar, sebanyak 9 anggota fitness menjawab 4 soal dengan benar, sebanyak 8anggota fitness menjawab 3 soal dengan benar, sebanyak 6 anggota fitness menjawab 2 soal dengan benar, sebanyak 4 anggota fitness menjawab 1 soal dengan benar, sebanyak 1 anggota fitness tidak dapat menjawab sama sekali.

\section{Pemahaman anggota fitness Tentang cairan tubuh.}

Di bawah ini disajikan data mengenai pemahaman anggota fitness tentang cairan tubuh. memberikan informasi pemahaman anggota fitness tentang cairan tubuh dengan nilai tertinggi sebesar 91,6 dan nilai terendah 41,6 dengan rentang nilai 50 dan nilai rata-rata 67 dan memiliki standar deviasi 32,4.

Dari hasil perhitungan dimensi cairan tubuh, terdapat 1 anggota fitness yang dapat menjawab pertanyaan 11 soal dengan benar, sebanyak 6 anggota fitness menjawab 10 soal dengan benar, sebanyak 4 anggota fitness menjawab 9 soal dengan benar, sebanyak 5 anggota fitness menjawab 8 soal dengan benar, sebanyak 6 anggota fitness menjawab 7 soal dengan benar, sebanyak 5 anggota fitness menjawab 6 soal dengan benar, sebanyak 3 anggota fitnessmenjawab 5 soal dengan benar.

\section{Pemahaman Anggota Fitness TentangDehidrasi.}

Di bawah ini disajikan data mengenai dehidrasi. Informasi pemahaman anggota fitness tentang dehidrasi dengan nilai tertinggi sebesar 100 dan nilai terendah 33,3 dengan rentang nilai 66,7 dan nilai rata-rata 63,3 dan memiliki standar deviasi 19,34 .

Dari hasil perhitungan dimensi dehidrasi, terdapat 1 anggota fitness yang dapat menjawab pertanyaan 12 soal dengan benar, sebanyak 1 anggota fitness menjawab 11 soal dengan benar, sebanyak 7 anggota fitness menjawab 10 soal dengan benar, sebanyak 1 anggota fitness menjawab 9 soal dengan benar, sebanyak 6 anggota fitness 
menjawab 8 soal dengan benar, sebanyak 4 anggota fitness menjawab 7 soal dengan benar, sebanyak 4 anggota menjawab 6 soal dengan benar, terdapat 1 anggota fitness yang dapat menjawab pertanyaan 5 soal dengan benar, sebanyak 4 anggota fitness menjawab 4 soal dengan benar, sebanyak 4 personal anggota fitness menjawab 9 soal dengan benar.

\section{PENUTUP}

Kesimpulan. Pemahaman Anggota Fitness Tentang Pencegahan Dan Bahaya Dehidrasi Saat Joging Di Elite Klub Epicenterum Jakarta Selatan. Berdasarkan dari berbagai pengukuran yang telah dilakukan untuk masingmasing dimensi yang diukur dari aspek saat joging, cairan tubuh, dan dehidrasi.

Informasi Pemahaman Anggota Fitness Tentang Pencegahan Dan Bahaya Dehidrasi Saat Joging Di Elite Klub Epicenterum Jakarta Selatan dengan nilai tertinggi sebesar 86 dan nilai terendah 40 , dengan rentang nilai 46 dan nilai rata-rata 61 dan memiliki standar deviasi 12,34.Dari data di atas menunjukan sebanyak 3 anggota fitness memiliki pemahaman yang baik, 19 anggotafitness memiliki pemahaman yang cukup, 8 anggota fitness memiliki pemahaman yang kurang. Hasil pemahaman anggota fitness rata-rata cukup sebesar $(61 \%)$.

Saran. Dengan adanya hasil penelitian di atas, maka disarankan :

1. Bagi setiap siswa hendaknya mengetahui indeks Massa Tubuh dan kebugaran jasmani yang ideal bagi mereka.

2. Kebugaran jasmani pada anak Santa Maria Fatima harus ditingkatkan.

3. Bagi para pendidik khususnya guru Pendidikan Jasmani Olahraga dan Kesehatan
(PJOK) hendaknya mau untuk membuat kreatifitas dan inovasi dalam membuat materi pembelajaran kepada siswa contohnya dengan memberikan materi pembelajaran PJOK bagi siswa guna menunjang perkembangan fisik anak.

4. Bagi sekolah hendaknya untuk memfasilitasi guru dan siswa untuk menyediakan alat untuk semakin meningkatkan kebugaran jasmani anak.

\section{DAFTAR RUJUKAN}

Hari Setiono. Buku Pedoman Biomekanika dan Kebugaran Jasmani, Jakarta: KEMENEGPORA RI, 2008.

Lutan, Rusli, Hartoto, Tomolius. Pendidikan Kebugaran Jasmani. Jakarta: Direktoral Jenderal Olahraga Depdiknas, 2001.

Mochamad Djumidar A. Widya. Belajar Berlatih Gerak-Gerak Dasar Atletik Dalam Bermain, Jakarta: Fakultas Ilmu Keolahragaan Universitas Negeri Jakarta, 2002.

M. Sajono. Peningkatan dan Pembinaan Kekuatan Kondisi Fisik Dalam Olahraga. Jakarta, 1982

Nurhasa. Tes dan Pengukuran dalam pendidikan Jasmani . Prinsipprinsip dan Penerapannya. Jakarta: DEPDIKNAS, 2001.

Pusat Kesegaran Jasmani. Tes Kesegaran Jasmani Indonesia. Jakarta: Departemen Pendidikan Nasional, 1999.

Rahadian, Bayu, dkk. Pedoman Biomekanik dan Kebugaran Jasmani. Jakarta: Kementerian Negara Pemuda dan Olahraga Republik Indonesia, 2008. 
Sadoso Sumosardjono. Olahraga dan Kesehatan dari A sampai Z, Jakarta, Pustaka Kartini, 1989.

Sudijono, Anas. Pengantar Statistik Pendidikan. Jakarta: PT. RajaGrafindo Persada, 2010.

Sutopo, Arie.S. Dan Alma Permana Lestari, Buku Penuntun Praktikum Ilmu Faal Kerja (Ergofisiologi)

Sumosardjuno, Sadoso. Olahraga dan Kesehatan dari A sampai Z. Jakarta: Pustaka Kartini, 1989.

Widiastuti. Tes dan Pengukuran Olahraga. Jakarta: PT. Bumi Timur Raya, 2011.

Widya, Mochamad Djumidar A. Belajar Berlatih Gerak-Gerak Dasar Atletik Dalam Bermain. Jakarta: Fakultas Ilmu Keolahragaan Universitas Negeri Jakarta.

Winarno, dkk. Jurnal Pendidikan Jasmani. Jakarta: Jurusan Sosiokinetika Fakultas Ilmu Keolahragaan Universitas Negeri Jakarta, 2009.

http://www.medkes.com/2013/11/kalkulat or-imt-ukur-berat-badan-ideal.html http://www.pusatbahasa.go.id/kbbi/kamus http://ilmugizieducation.blogspot.com 